\title{
SISTEM PENENTUAN RUTE PENDISTRIBUSIAN PRODUK AIR MINERAL MENGGUNAKAN ALGORITMA ANT COLONY SYSTEM
}

\author{
Deny Wiria Nugraha ${ }^{1}$, Albrecht Yordanus Erwin Dodu², Stevi Septiana ${ }^{3}$ \\ 1'deny.wiria.nugraha@gmail.com, 2ayerwin.dodu@gmail.com, ${ }^{3}$ steviseptiana27@gmail.com \\ 1,2,3 Jurusan Teknologi Informasi, Fakultas Teknik, Universitas Tadulako
}

\begin{abstract}
Abstrak
Permasalahan penentuan rute distribusi dapat dikategorikan sebagai Travelling Salesman Problem (TSP). TSP merupakan pencarian urutan lokasi dimana seorang salesman melakukan perjalanan dari lokasi awal menuju daftar sejumlah lokasi yang harus dilalui. Setiap lokasi hanya boleh dikunjungi satu kali dan berakhir pada lokasi awal keberangkatan. Penelitian ini bertujuan untuk menyelesaikan masalah penentuan rute pendistribusian produk air mineral pada PT. Anugerah Wina Sentosa dengan mengimplementasikan algoritma Ant Colony System (ACS) untuk melakukan pencarian rute. Algoritma ACS merupakan algoritma yang diadopsi dari perilaku semut untuk menentukan rute terpendek dari sarang menuju sumber makanan. Berdasarkan penelitian, hasil algoritma ACS menunjukan bahwa semakin besar kasus yang akan diselesaikan maka berpengaruh pada waktu eksekusi sistem namun tetap dapat menghasilkan rute dengan jarak terbaik. Keberhasilan algoritma ini dipengaruhi oleh penentuan nilai parameter ACS yaitu $\beta, q o, q, \alpha, P$, jumlah semut dan jumlah siklus semut yang ditentukan dengan melakukan analisa berdasarkan kasus TSP yang akan diselesaikan.
\end{abstract}

Kata kunci: Travelling Salesman Problem (TSP), Ant Colony System (ACS)

\section{Abstract}

The problem of determining distribution routes can be categorized as Traveling Salesman Problem (TSP). TSP is a search for a sequence of locations where a salesman travels from the initial location to a list of locations which must be passed. Each location can only be visited once and ends at the initial location of departure. This study aims to resolve the problem of determining the distribution route for mineral water products at PT. Anugerah Wina Sentosa by implementing the Ant Colony System (ACS) algorithm to conduct route searches. The ACS algorithm is an algorithm adopted from the behavior of ants to determine the shortest route from the nest to the food source. Based on the research, the results of the ACS algorithm show that the greater the case to be resolved will affect the system execution time but still can produce the best distance route. The success of this algorithm is influenced by the determination of the value of the ACS parameter, namely $\beta, q o, q, \alpha, P$, the number of ants and the number of ant cycles determined by analyzing the TSP case to be resolved.

Keywords: Travelling Salesman Problem (TSP), Ant Colony System (ACS)

\section{Pendahuluan}

Kegiatan distribusi merupakan kegiatan yang sering dilakukan untuk menyalurkan hasil produksi kepada para konsumen. Dalam dunia industri, pendistribusian yang baik sangat penting karena berpengaruh pada pengoptimalan biaya, kualitas barang serta ketepatan waktu pengantaran.

Kegiatan pendistribusian juga terjadi pada PT. Anugerah Wina Sentosa yang merupakan produsen air mineral yang cukup besar di kota Palu. Produsen air mineral ini memiliki pelanggan tetap yang menerima produk air mineral berupa kemasan galon dan gelas $(250 \mathrm{ml}$ dan $220 \mathrm{ml})$ setiap harinya sesuai jadwal pengantaran produk yang dilakukan oleh lima kendaraan milik perusahaan pada masing-masing wilayah yang telah ditentukan. Banyaknya pelanggan tetap pada produsen air mineral ini membuat perusahaan harus menjaga kepercayaan para konsumen dengan memberikan pelayanan yang baik yaitu mengantarkan produk air mineral dengan kualitas yang tinggi dan tepat waktu.

Proses pendistribusian produk air mineral PT. Anugerah Wina Sentosa disalurkan kepada para pelanggan dengan mengunjungi semua agen/toko yang telah terjadwal walaupun agen/toko tidak mengambil produk yang sudah dibawa. Dalam hal ini, karyawan yang bertugas mengemudikan kendaraan harus memilih rute perjalanan terbaik untuk mengujungi setiap agen/toko. Namun banyaknya jalur menuju tempat tujuan terkadang membuat pengemudi memilih jalur atau rute pendistribusian yang kurang tepat. Hal ini dapat menyebabkan kurang efisiennya jarak pengantaran produk sehingga kegiatan pendistribusian menjadi tidak optimal. 
ILKOM Jurnal Ilmiah Volume 11 Nomor 2 Agustus 2019 Terakreditasi peringkat 3 SK. No. 28/E/KPT/2019

Permasalahan penentuan rute pada penelitian ini tanpa mempertimbangkan kapasitas kendaraan serta mengikuti aturan bahwa lokasi-lokasi pendistribusian hanya dikunjungi satu kali dapat dikategorikan sebagai permasalahan Travelling Salesman Problem (TSP) yang kemudian akan diselesaikan menggunakan algoritma Ant Colony System (ACS).

Ant Colony System (ACS) merupakan algoritma pemecahan masalah optimasi yang terinspirasi dari tingkah laku semut dari sarang menuju sumber makanan. Secara alamiah koloni semut mampu menemukan rute terpendek dalam perjalanan dari sarang ke tempat-tempat sumber makanan. Hal tersebut dapat dilakukan dengan meninggalkan jejak pheromone untuk berkomunikasi dengan semut lainnya.

Dalam penelitiannya, Amalia (2015) meneliti tentang pencarian jalur terpendek menggunakan Ant Colony System (Kasus: Pariwisata Kota Bogor). Penelitian ini bertujuan untuk membantu agen travel atau Dinas Pariwisata dan Kebudayaan kota Bogor untuk memberikan alternatif terbaik bagi para wisatawan untuk menguji obyek-obyek wisata yang ada di kota Bogor. Pencarian jalur terpendek menggunakan Ant Colony Sytem mendapatkan pilihan terbaik dalam mengunjungi obyek obyek wisata yang ada di kota Bogor dengan memperhitungkan efisiensi waktu dan biaya. Pemilihan rute dengan menggunakan algoritma Ant Colony System pada 9 obyek wisata kota Bogor menghasilkan rute dengan jarak tempuh sejauh 27482 meter [1].

Dalam penelitiannya, Gunawan dkk (2015) membuat perancangan sistem informasi penentuan rute pengiriman barang dengan metode Ant Colony Optimization studi kasus: PT. XYZ. Penelitian ini dilakukan untuk mengatasi masalah kegiatan pendistribusian yang sering mengalami keterlambatan pengiriman pesanan kepada konsumen. Dari hasil penelitian ini, pengolahan data menggunakan metode Ant Colony Optimization untuk perancangan rute yang menangani 30 pesanan, metode Ant Colony Optimization dapat mengurangi keterlambatan sebesar $10 \%$ dari keterlambatan [2].

Dalam penelitiannya, Tutupary dkk (2014) membuat aplikasi algoritma Ant Colony System dalam penentuan rute optimum distribusi BBM pada PT. Burung Laut. Penelitian ini dilakukan untuk membandingkan rute hasil pencarian algoritma Ant Colony System dengan rute yang tidak pasti atau system tramper dalam pendistribusian BBM yang dilakukan oleh PT. Burung Laut dari kota Ambon ke 13 lokasi disekitarnya. Hasil dari penelitian ini membuktikan bahwa dengan menggunakan algoritma Ant Colony System, jarak rute pendistribusian BBM dapat ditempuh sejauh 5.262 mil dengan waktu tempuh 3,09 minggu. Sedangkan menggunakan sistem tramper, jarak rute yang harus ditempuh untuk pendistribusian BBM sejauh 5.798 mil dalam waktu 3,37 minggu. Dari hasil penelitian, rute yang didapatkan oleh algoritma Ant Colony System mendapatkan nilai yang lebih baik sehingga membuktikan bahwa algoritma ini dapat digunakan untuk mendapatkan rute yang lebih baik [3].

Berdasarkan masalah yang dihadapi oleh PT. Anugerah Wina Sentosa seperti yang dijabarkan maka solusi yang dapat dilakukan adalah membuat sebuah sistem yang memanfaatkan google maps API dan implementasi algoritma Ant Colony System (ACS) untuk menggambarkan dan menentukan jalur-jalur terpendek yang dapat dilalui oleh driver kendaraan pengantar produk air mineral. Sistem ini akan dibangun berbasis web dan terbagi dalam dua sistem yakni sistem admin dan sistem drvier. Sistem admin merupakan sistem yang dirancang untuk melakukan pengolahan data kendaraan, pelanggan dan rute distribusi sedangkan sistem driver merupakan sistem yang dirancang untuk driver agar dapat melihat rute pendistribusian secara online. Penelitian ini bertujuan untuk membantu menyelesaikan masalah pada PT. Anugerah Wina Sentosa dalam menentukan rute terbaik untuk mendistribusikan produk air mineral hasil produksi perusahaan kepada para pelanggan di seluruh kota Palu dengan jarak yang lebih baik.

\section{Metode}

\subsection{Graph}

Graph adalah kumpulan dari simpul dan busur yang secara matematis dinyatakan sebagai $\mathrm{G}=$ $(\mathrm{V}, \mathrm{E})$, dimana: $\mathrm{G}=$ graph, $\mathrm{V}=$ simpul atau vertex, $\mathrm{E}=$ busur atau edge. Graph terdiri dari graph berbobot dan tak berbobot [4].

\subsection{Travelling Salesman Problem (TSP)}

Traveling Salesman Problem (TSP) merupakan permasalahan optimasi kombinatorial dimana terdapat seorang salesman yang ingin mengunjungi seluruh kota pada suatu daerah tepat satu kali dan harus kembali ke kota awal keberangkatan. Penyelesaian dari TSP adalah rute dengan bobot minimum. Beberapa permasalahan yang dapat diselesaikan dengan TSP adalah permasalahan perencanaan kunjungan wisata, logistik, integrated circuit (IC), dan lain-lain [5][6][7]. 
ILKOM Jurnal Ilmiah Volume 11 Nomor 2 Agustus 2019 Terakreditasi peringkat 3 SK. No. 28/E/KPT/2019

\subsection{Algoritma Ant Colony System (ACS)}

Menurut Dorigo dan Gambardella (dalam Amalia, 2015) ACS memiliki tiga aspek utama yaitu pertama aturan transisi status, pada sistem ini memberikan suatu cara langsung untuk menyeimbangkan antara penjelajahan (exploration) ruas-ruas yang baru dengan eksploitasi (exploitation) dari sebuah priori dan pengetahuan yang dihimpun mengenai masalah tersebut, kedua yaitu disaat ants membangun sebuah solusi, diterapkan suatu aturan pembaruan pheromone lokal (local pheromone updating rule) dan ketiga yaitu aturan pembaruan pheromone global yang hanya dilakukan pada ruas-ruas yang merupakan bagian dari tur terbaik [1][8].

\subsection{Karakteristik Algoritma Ant Colony System (ACS)}

Terdapat tiga karakteristik utama dari ACS, yaitu aturan transisi status, aturan pembaruan pheromone lokal dan aturan pembaruan pheromone global.

1. Aturan Transisi Status

Aturan transisi status yang berlaku pada ACS adalah sebagai berikut: seekor semut yang ditempatkan pada titik $t$ memilih untuk menuju ke titik $v$, kemudian diberikan bilangan pecahan acak $q$ dimana $0 \leq q \leq 1, q_{0}$ adalah sebuah parameter yaitu probabilitas semut melakukan eksplorasi pada setiap tahapan, dimana $\left(0 \leq q_{0} \leq 1\right)$ dan $p_{k}(t, v)$ adalah probabilitas dimana semut $\mathrm{k}$ memilih untuk bergerak dari titik $t$ ke titik $v$. Jika $q \leq q_{0}$ maka pemilihan titik yang akan dituju menerapkan aturan yang ditunjukkan oleh persamaan (1).

$$
\begin{aligned}
& \text { temporary }(t, u)=\left[\tau\left(t, u_{i}\right)\right] \cdot\left[\eta\left(t, u_{i}\right)\right]^{\beta}, i=1,2,3 \ldots, n \\
& v=\max \left\{\left[\tau\left(t, u_{i}\right)\right] \cdot\left[\eta\left(t, u_{i}\right)\right]^{\beta}\right\}
\end{aligned}
$$

dengan $\mathrm{v}=$ titik yang akan dituju sedangkan jika $q>q_{0}$ digunakan persamaan (2).

$$
v=p_{k}(t, v)=\frac{[\tau(t, v)]\left[\eta_{i}(t, v)\right]^{\beta}}{\sum_{i=1}^{n}\left[\tau\left(t, u_{i}\right)\right] \cdot\left[\eta\left(t, u_{i}\right)\right]^{\beta}}
$$

dengan $\eta\left(t, u_{i}\right)=\frac{1}{\operatorname{jarak}\left(t, u_{i}\right)}$ dimana $\tau(t, u)$ adalah nilai dari jejak pheromone pada titik $(t, u), \eta(t, u)$

adalah fungsi heuristik dimana dipilih sebagai invers jarak antara titik $t$ dan $u, \beta$ merupakan sebuah parameter yang mempertimbangkan kepentingan relatif dari informasi heuristic, yaitu besarnya bobot yang diberikan terhadap parameter informasi heuristik, sehingga solusi yang dihasilkan cenderung berdasarkan nilai fungsi matematis. Nilai untuk parameter $\beta$ adalah $\geq 0$.

\section{Aturan Pembaruan Pheromone Lokal}

Selagi melakukan tur untuk mencari solusi dari TSP, semut mengunjungi ruas-ruas dan mengubah tingkat pheromone pada ruas-ruas tersebut dengan menerapkan aturan pembaruan pheromone lokal yang ditunjukan oleh persamaan (3).

$$
\begin{aligned}
& \tau(t, v) \leftarrow(1-\rho) \cdot \tau(t, v)+\rho \cdot \Delta \tau(t, v) \\
& \Delta \tau(t, v)=\frac{1}{L C} \\
& \text { dimana: } \\
& \rho \quad=\text { Parameter dengan nilai } 0 \text { sampai } 1 \\
& \Delta \mathrm{T} \quad=\text { Perubahan pheromone } \\
& L \quad=\text { Panjang tur yang diperoleh antar } t \text { dan } v \\
& C \quad=\text { Jumlah node }
\end{aligned}
$$

$P$ adalah sebuah parameter (koefisien evaporasi), yaitu besarnya koefisien penguapan pheromone. Adanya penguapan pheromone menyebabkan tidak semua semut mengikuti jalur yang sama dengan semut sebelumnya.

\section{Aturan Pembaruan Pheromone Global}

Pada sistem ini, pembaruan pheromone secara global hanya dilakukan oleh semut yang membuat tur terpendek sejak permulaan percobaan. Pada akhir sebuah iterasi, setelah semua semut menyelesaikan tur mereka, sejumlah pheromone ditaruh pada ruas-ruas yang dilewati oleh seekor semut yang telah menemukan tur terbaik (ruas-ruas yang lain tidak diubah). Tingkat pheromone itu diperbarui dengan menerapkan aturan pembaruan pheromone global yang ditunjukkan oleh persamaan (4).

$$
\begin{aligned}
& \mathrm{T}(\mathrm{t}, \mathrm{V}) \leftarrow(1-\alpha) \cdot \mathrm{T}(\mathrm{t}, \mathrm{v})+\alpha \cdot \Delta \mathrm{T}(\mathrm{t}, \mathrm{V}) \\
& \Delta \tau(t, v)\left\{_{0}^{l_{g b}^{-1} j i k a}(t, v) \in\right. \text { tur_terbaik }
\end{aligned}
$$


ILKOM Jurnal Ilmiah Volume 11 Nomor 2 Agustus 2019

Terakreditasi peringkat 3 SK. No. 28/E/KPT/2019

Dimana:

$T(t, v)=$ Nilai pheromone akhir setelah mengalami pembaruan lokal

$L_{g b}=$ Panjang jalur terpendek pada akhir siklus

$\alpha \quad=$ Parameter dengan nilai antara 0 sampai 1

$\Delta \mathrm{T} \quad=$ Perubahan pheromone

$\Delta \mathrm{T}(t, v)$ bernilai $1 / L_{g b}$ jika ruas $(\mathrm{t}, \mathrm{v})$ merupakan bagian dari rute terbaik namun jika sebaliknya $\Delta \mathrm{T}(t, v)$ $=0$. $\alpha$ adalah tingkat kepentingan relatif dari pheromone atau besarnya bobot yang diberikan terhadap pheromone, sehingga solusi yang dihasilkan cenderung mengikuti sejarah masa lalu dari semut dari perjalanan sebelumnya, dimana nilai parameter $\alpha$ adalah $\geq 0$, dan $L_{g b}$ adalah panjang dari tur terbaik secara global sejak permulaan percobaan.

\section{Hasil dan Pembahasan}

\subsection{Sistem Penentuan Rute Pendistribusian Produk Air Mineral}

Sistem penentuan rute pendistribusian produk air mineral memiliki dua bagian sistem yakni sistem administrator dan sistem driver. Sistem administrator dapat melakukan pengolahan data sedangkan sistem driver digunakan untuk melihat hasil pengolahan data dari sistem admin berupa lokasi pelanggan dan rute distribusi. Halaman hasil lokasi pelanggan dapat dilihat pada gambar 1. dan halaman hasil rute distribusi produk air mineral dapat dilihat pada gambar 2.

\section{Locations}

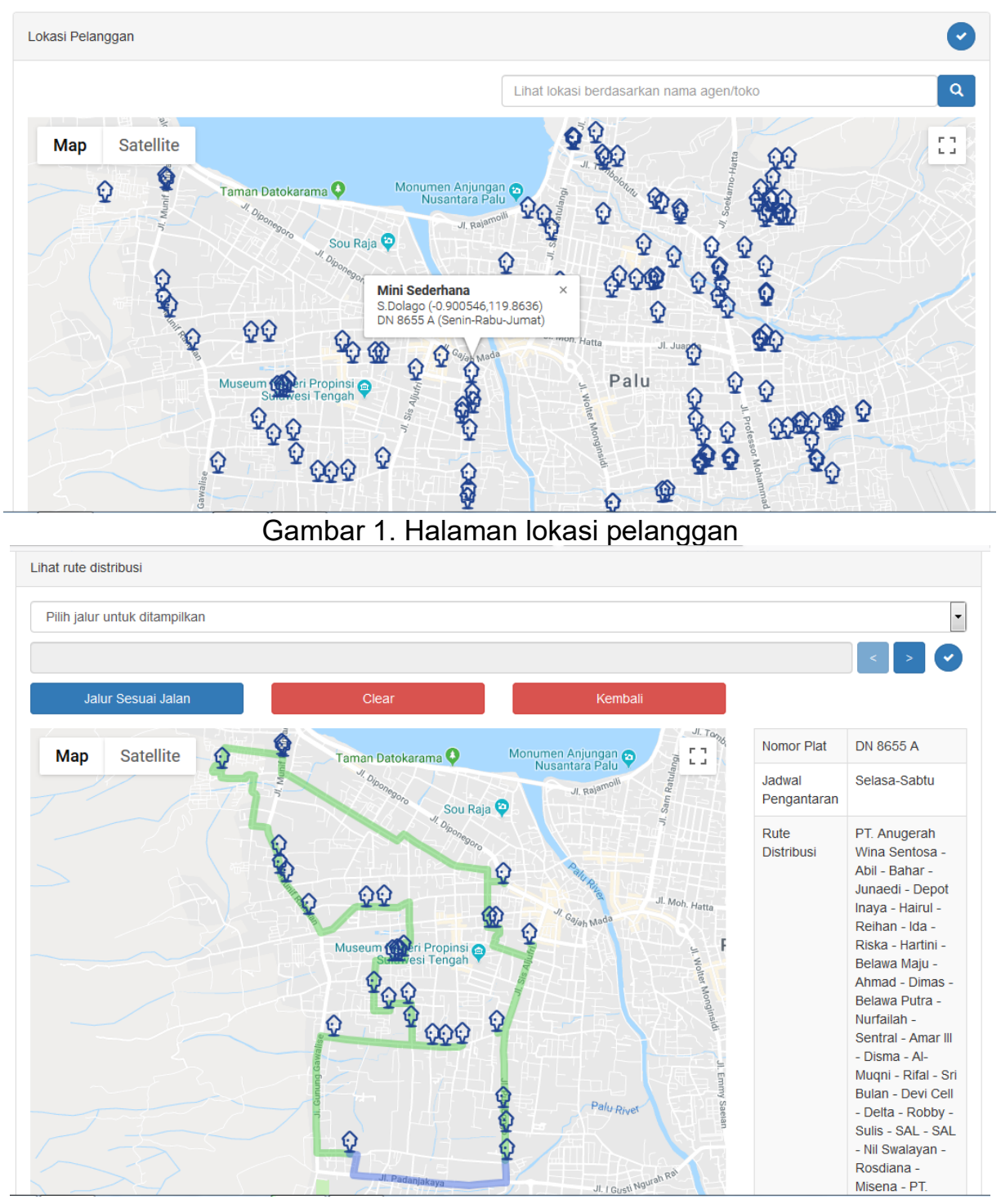


ILKOM Jurnal Ilmiah Volume 11 Nomor 2 Agustus 2019

Terakreditasi peringkat 3 SK. No. 28/E/KPT/2019

\subsection{Implementasi Algoritma Ant Colony System (ACS)}

Gambar 2. Halaman rute distribusi

Implementasi algoritma ACS dalam sistem dapat digambarkan pada flowchart ACS untuk penyelesaian TSP yang dapat dilihat pada gambar 3 .

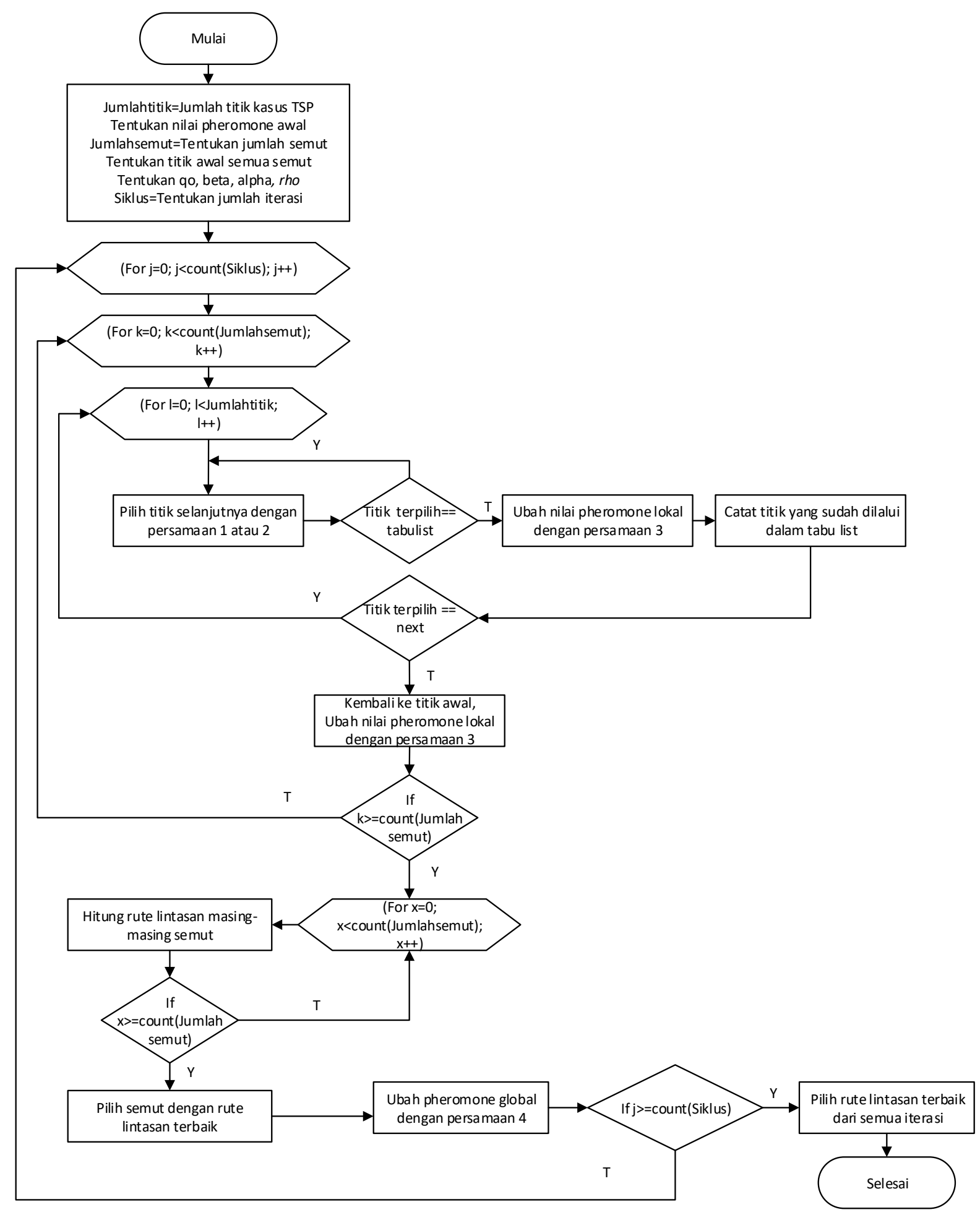

Gambar 3. Flowchart ACS untuk penyelesaian TSP 
ILKOM Jurnal Ilmiah Volume 11 Nomor 2 Agustus 2019

Terakreditasi peringkat 3 SK. No. 28/E/KPT/2019

Berikut adalah ilustrasi implementasi algoritma ACS dalam menemukan rute distribusi dari lokasi perusahaan menuju beberapa lokasi pelanggan. Gambar lokasi pelanggan yang akan dilakukan ilustrasi pencarian rute dapat dilihat pada gambar 4 .

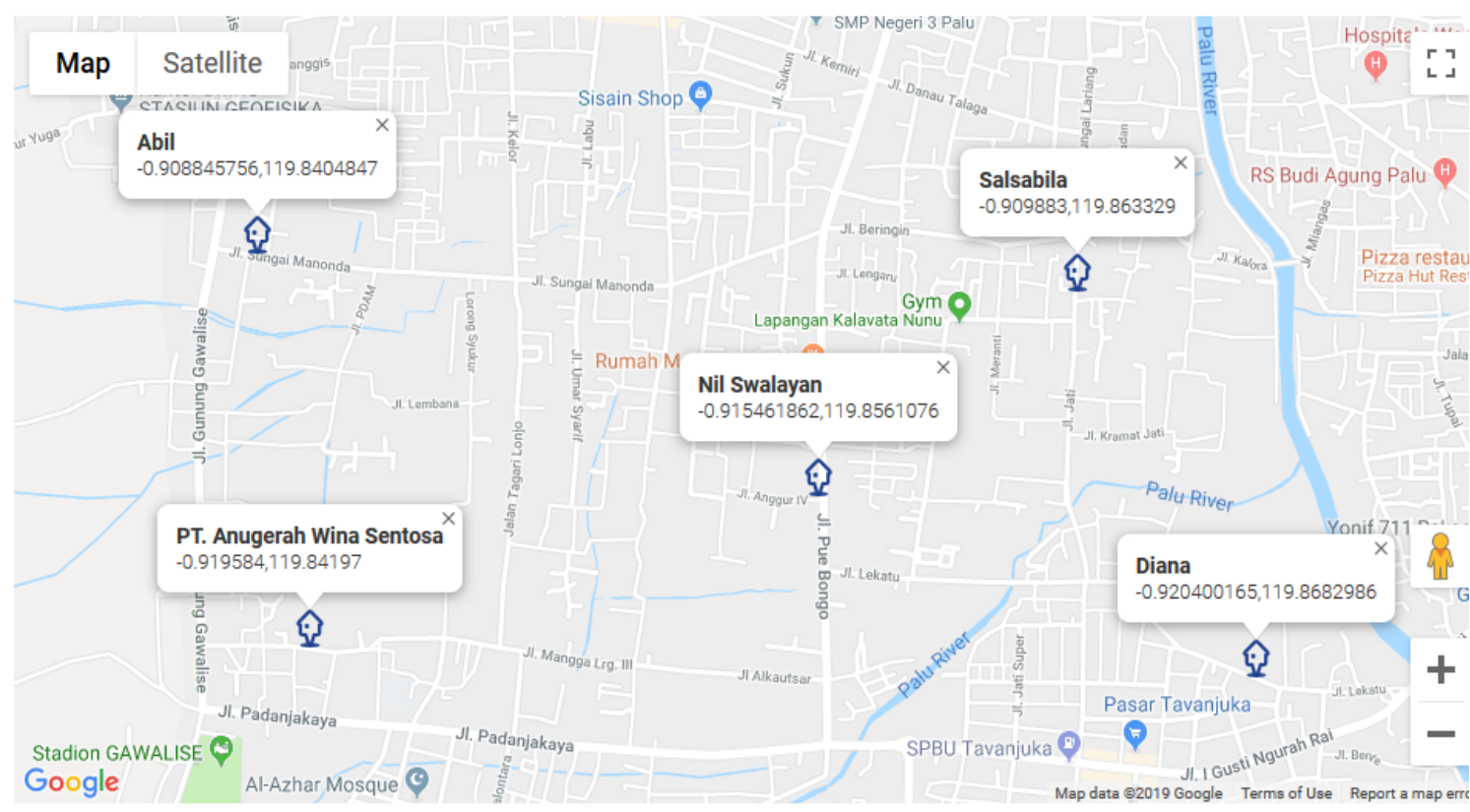

Gambar 4. Lokasi ilustrasi pelanggan

Jarak antar pelanggan dapat direpresentasikan dalam bentuk tabel jarak yang dapat dilihat pada tabel 1.

Tabel 1. Jarak (KM)

\begin{tabular}{llllll}
\hline & $\mathrm{A}$ & $\mathrm{B}$ & $\mathrm{C}$ & $\mathrm{D}$ & $\mathrm{E}$ \\
\hline $\mathrm{A}$ & 0 & 1,68 & 3,66 & 2,62 & 3,56 \\
$\mathrm{~B}$ & 1,68 & 0 & 2,75 & 2,41 & 4,07 \\
$\mathrm{C}$ & 3,66 & 2,75 & 0 & 1,71 & 1,51 \\
$\mathrm{D}$ & 2,62 & 2,41 & 1,71 & 0 & 1,67 \\
$\mathrm{E}$ & 3,56 & 4,07 & 1,51 & 1,67 & 0 \\
\hline
\end{tabular}

Keterangan:
A : PT. Anugerah Wina Sentosa
B : Abil
C : Salsabila
D : Nil Swalayan
E : Diana

Selanjutnya dilakukan proses pembuatan rute dengan beberapa tahap sebagai berikut :

1. Pembuatan tabel invers jarak

Nilai invers jarak dihasilkan dari $\left(t, u_{i}\right)=\frac{1}{\operatorname{jarak}\left(t, u_{i}\right)}$. Tabel invers jarak dapat dilihat pada tabel 2 .

Tabel 2. Invers jarak

\begin{tabular}{cccccc} 
& A & B & C & D & E \\
\hline A & 0 & 0,59 & 0,27 & 0,38 & 0,28 \\
B & 0,59 & 0 & 0,36 & 0,41 & 0,24 \\
C & 0,27 & 0,36 & 0 & 0,58 & 0,66 \\
D & 0,38 & 0,41 & 0,58 & 0 & 0,6 \\
E & 0,28 & 0,24 & 0,66 & 0,6 & 0 \\
\hline
\end{tabular}


ILKOM Jurnal Ilmiah Volume 11 Nomor 2 Agustus 2019 Terakreditasi peringkat 3 SK. No. 28/E/KPT/2019

\section{Penentuan pheromone awal}

Nilai pheromone awal dihasilkan dari $\tau_{0}=\frac{1}{n\left(c^{n n}\right)}$ dimana $n$ adalah jumlah titik yang ada pada masalah sedangkan $C^{n n}$ merupakan panjang atau jarak rute yang dihasilkan dari metode Nearest Neighboard. Tabel pheromone awal dapat dilihat pada tabel 3.

Tabel 3. Pheromone awal

\begin{tabular}{cccccc}
\hline & $\mathrm{A}$ & $\mathrm{B}$ & $\mathrm{C}$ & $\mathrm{D}$ & $\mathrm{E}$ \\
\hline $\mathrm{A}$ & 0,000018 & 0,000018 & 0,000018 & 0,000018 & 0,000018 \\
$\mathrm{~B}$ & 0,000018 & 0,000018 & 0,000018 & 0,000018 & 0,000018 \\
$\mathrm{C}$ & 0,000018 & 0,000018 & 0,000018 & 0,000018 & 0,000018 \\
$\mathrm{D}$ & 0,000018 & 0,000018 & 0,000018 & 0,000018 & 0,000018 \\
$\mathrm{E}$ & 0,000018 & 0,000018 & 0,000018 & 0,000018 & 0,000018 \\
\hline
\end{tabular}

3. Penentuan parameter ACS

Parameter yang digunakan pada algoritma ACS dapat diinisialisasi secara berbeda-beda untuk setiap kasus karena hasil yang didapatkan algoritma ini bergantung pada nilai parameter yang ditentukan. Jika inisialisasi parameter tidak tepat maka dapat berpengaruh pada hasil jarak dan waktu eksekusi algoritma yang cenderung akan lebih lama. Pada kasus ilustrasi ini digunakan parameter dengan nilai $\beta=2$, qo $=0.9, \rho=0.1, \alpha=0.1$, jumlah semut $=10$ dan jumlah siklus semut/iterasi $=$ 5 .

\section{Proses algoritma ACS}

Setelah proses penentuan parameter telah selesai selanjutnya agen-agen semut ditempatkan pada setiap titik secara random untuk mengunjungi setiap titik-titik yang terhubung melalui proses transisi status. Proses transisi status dipengaruhi oleh pemilihan nilai parameter qo $\left(0 \leq q_{0} \leq 1\right)$ dan nilai random dari nilai parameter q $(0 \leq q \leq 1)$. Pada proses ini semut akan memilih untuk melakukan eksploitasi (jika $q \leq q_{0}$ ) dengan melakukan perhitungan $v=\max \left\{\left[\tau\left(t, u_{i}\right)\right] \cdot\left[\eta\left(t, u_{i}\right)\right]^{\beta}\right\}$ atau eksplorasi (jika $q>q_{0}$ ) dengan melakukan perhitungan $v=p_{k}(t, v)=\frac{[\tau(t, v)]\left[\eta[(t, v)]^{\beta}\right.}{\sum_{i=1}^{n}\left[\tau\left(t, u_{i}\right)\right] \cdot\left[\eta\left(t, u_{i}\right)\right]^{8}}$. Eksploitasi berarti semut hanya akan mengunjungi ruas-ruas simpul yang memiliki pheromone yang tinggi dengan bobot jarak yang kecil sedangkan ekplorasi berarti semut bisa saja mengunjungi ruas-ruas simpul yang memiliki pheromone yang tinggi dengan bobot jarak yang kecil atau ruas-ruas simpul yang memiliki pheromone yang rendah dengan bobot jarak yang besar.

Dalam proses perjalanan setiap semut, proses transisi status dilakukan secara berulang-ulang hingga semua titik berhasil dikunjungi dan menandai setiap titik yang telah dikunjunginya dengan menyimpannya pada tabu list yang dimiliki oleh masing-masing semut. Titik yang telah tersimpan dalam tabu list semut menjadi daftar titik terlarang yang tidak boleh dikunjungi lagi oleh semut tersebut.

Selagi membangun tur, setiap kali semut telah memilih titik melalu proses transisi status, maka akan dilakukan proses pembaharuan pheromone lokal pada ruas titik yang sudah dipilih dengan melakukan perhitungan $\tau(t, v) \leftarrow(1-\rho) \cdot \tau(t, v)+\rho \cdot \Delta \tau(t, v)$. Tujuan pembaruan pheromone lokal adalah untuk mengurangi ketertarikan ruas dengan melakukan penguapan pheromone pada ruas simpul yang telah dilaluinya sehingga semut-semut lain tidak akan terjebak atau melalui titik yang sama secara terus-menerus.

Setelah semua semut menyelesaikan kunjungannya hingga tidak ada lagi titik yang tersisa maka semut akan kembali pada titik awal nya kemudian menghitung jarak atau bobot tiap titik yang sudah dilalui. Hasil bobot jarak yang dihasilkan setiap semut akan dibandingkan dan memilih satu jalur semut dengan hasil bobot jarak terkecil. Semut dengan bobot jarak yang paling kecil akan mengalami pembaruan pheromone global dengan melakukan perhitungan $\mathrm{T}(\mathrm{t}, \mathrm{v}) \leftarrow(1-\alpha) \cdot \mathrm{T}(\mathrm{t}, \mathrm{v})+\alpha \cdot \Delta \mathrm{T}(\mathrm{t}, \mathrm{v})$. Proses pembaruan pheromone global ini dapat menguatkan ketertarikan ruas yang pendek dan mengarahkan semut-semut untuk mendapatkan hasil yang lebih baik pada siklus semut atau iterasi selanjutnya.

Selanjutnya setelah satu siklus semut atau iterasi telah selesai, maka masing-masing semut akan mengosongkan daftar tabu list dan melakukan pencarian rute pada siklus selanjutnya hingga batasan siklus yang telah ditetapkan. Jika proses semua siklus telah selesai maka hasil setiap siklus akan dibandingkan dan mengambil rute dengan bobot yang paling kecil untuk dijadikan hasil akhir sebagai rute terbaik. 
ILKOM Jurnal Ilmiah Volume 11 Nomor 2 Agustus 2019

Terakreditasi peringkat 3 SK. No. 28/E/KPT/2019

Pada proses algoritma ini, setiap kali melakukan pencarian rute, hasil yang didapatkan tidak selalu sama karena algoritma ini mendapatkan hasil berdasarkan probabilitas atau peluang namun dapat menghasilkan hasil terbaik dengan mengatur nilai parameter yang tepat.

\section{Hasil pembuatan rute}

Hasil pembuatan rute menghasilkan rute terbaik pada semut ke 2 dalam proses siklus semut atau iterasi ke 1 dengan bobot jarak 10,24 KM dan waktu eksekusi pencarian rute 0,009 detik. Rute terbaik yang dihasilkan yaitu A - D - E - C - B - A dengan keterangan jalur yaitu PT. Anugerah Wina Sentosa Nil Swalayan - Diana - Salsabila - Abil - PT. Anugerah Wina Sentosa. Hasil rute dapat dilihat pada gambar 5 .

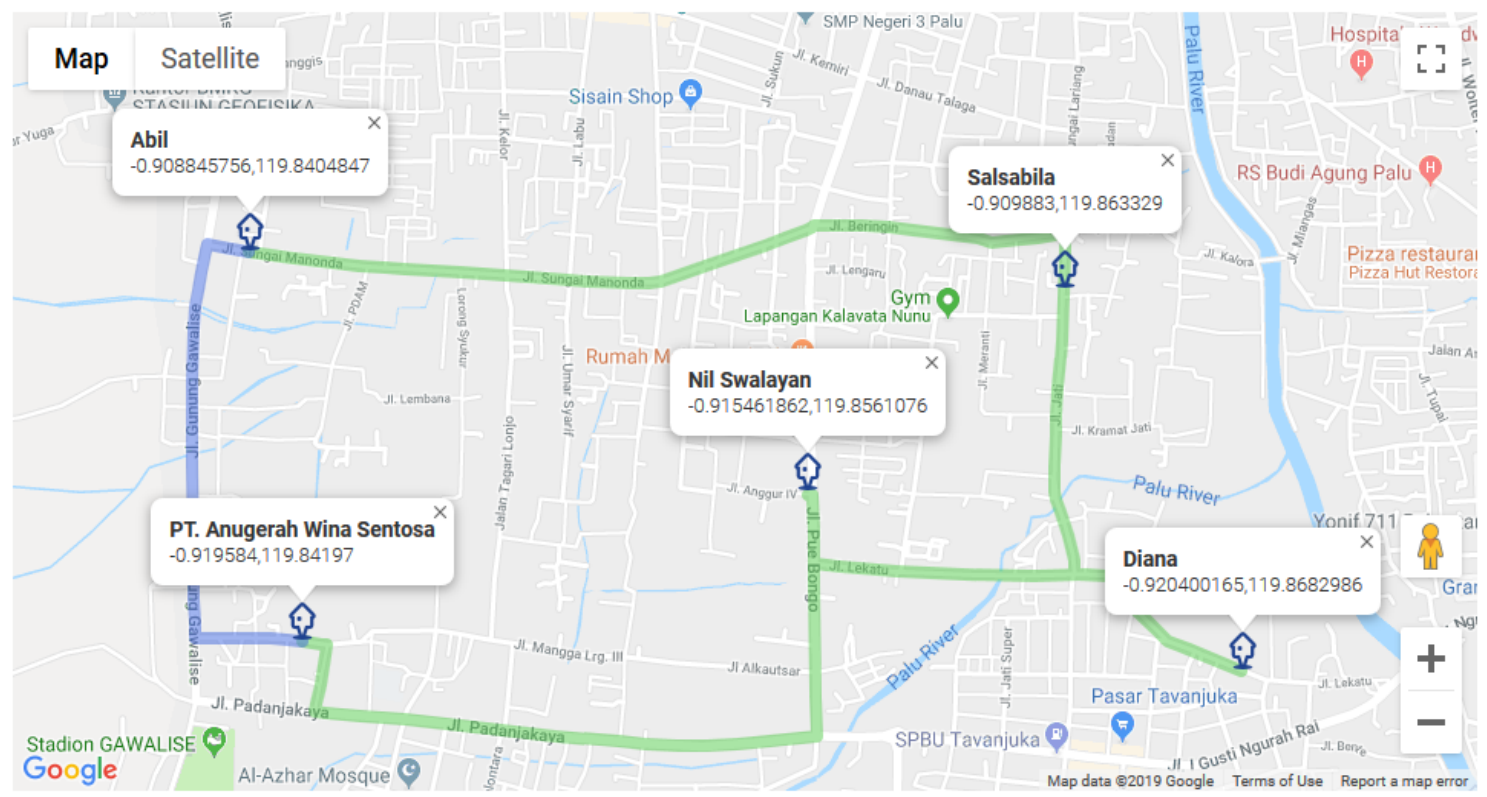

Gambar 5. Hasil rute

Dari hasil pembuatan rute pada gambar 5, jalur berwarna hijau merupakan jalur dimana driver memulai proses distribusi sampai pada titik pelanggan terakhir sedangkan jalur berwarna biru merupakan jalur dimana driver kembali ke lokasi perusahaan

\subsection{Pengujian Implementasi Algoritma ACS}

Pengujian implementasi algoritma ACS akan dilakukan pada 3 kasus yaitu kasus 20 titik, 50 titik dan kasus 100 titik. Hasil pengujian dapat dilihat pada tabel 4.

Tabel 4. Hasil pengujian implementasi algoritma ACS

\begin{tabular}{|c|c|c|c|}
\hline No. & $\begin{array}{c}\text { Jumlah } \\
\text { Titik }\end{array}$ & Jarak & $\begin{array}{l}\text { Waktu } \\
\text { eksekusi }\end{array}$ \\
\hline 1 & 20 & $9,382 \mathrm{KM}$ & 58,236 detik \\
\hline 2 & 20 & $9,346 \mathrm{KM}$ & 58,708 detik \\
\hline 3 & 20 & $9,346 \mathrm{KM}$ & 61,756 detik \\
\hline \multicolumn{2}{|c|}{ Rata-rata } & $9,413 \mathrm{KM}$ & $9,358 \mathrm{KM}$ \\
\hline 1 & 50 & $15,434 \mathrm{KM}$ & 370,045 detik \\
\hline 2 & 50 & $15,262 \mathrm{KM}$ & 373,159 detik \\
\hline 3 & 50 & $15,188 \mathrm{KM}$ & 454,313 detik \\
\hline \multicolumn{2}{|c|}{ Rata-rata } & $14,581 \mathrm{KM}$ & $15,295 \mathrm{KM}$ \\
\hline 1 & 100 & $35,582 \mathrm{KM}$ & 1405,151 detik \\
\hline 2 & 100 & $36,636 \mathrm{KM}$ & 1728,304 detik \\
\hline 3 & 100 & $36,423 \mathrm{KM}$ & 2073,598 detik \\
\hline \multicolumn{2}{|c|}{ Rata-rata } & $36,214 \mathrm{KM}$ & 1735,684 detik \\
\hline
\end{tabular}


ILKOM Jurnal Ilmiah Volume 11 Nomor 2 Agustus 2019

Terakreditasi peringkat 3 SK. No. 28/E/KPT/2019

Hasil pengujian pada tabel 4. memperlihatkan bahwa algoritma ini menghasilkan nilai yang ratarata berbeda setiap kali melakukan pencarian rute. Hal ini disebabkan oleh pencarian rute algoritma ACS dilakukan berdasarkan probabilitas atau peluang. Waktu eksekusi pada algoritma ini juga cenderung lebih lama jika kasus yang diselesaikan merupakan kasus yang memiliki banyak titik. Semakin banyak titik yang akan diselesaikan maka semakin lama waktu eksekusi proses pencarian rute dan sebaliknya.

\section{Kesimpulan dan Saran}

\subsection{Kesimpulan}

Dari hasil pembuatan sistem dapat disimpulkan bahwa sistem penentuan rute pendistribusian produk air mineral menggunakan algoritma Ant Colony System (ACS) dapat menghasilkan rute terbaik untuk mendistribusikan produk air mineral dari lokasi perusahaan menuju lokasi seluruh pelanggan di kota Palu. Sistem ini dapat membantu perusahaan untuk meminimalkan jarak tempuh driver dalam melakukan pendistribusian dengan jarak yang minimal.

Hasil penelitian algoritma ACS menunjukan bahwa ukuran kasus TSP berpengaruh pada waktu eksekusi algoritma ACS. Selain itu, penentuan nilai parameter (qo, $\beta, q, \rho, \alpha$, jumlah semut dan jumlah siklus semut/iterasi) untuk setiap kasus pada algoritma ACS sangat berpengaruh pada rute yang akan dihasilkan karena hal ini merupakan bagian penting untuk melakukan tahapan algoritma ACS yang meliputi transisi status, pembaruan pheromone lokal dan pembaruan pheromone global.

\subsection{Saran}

Berdasarkan kesimpulan penelitian, maka penulis merekomendasikan berupa saran untuk membangun sebuah sistem analisis pemilihan parameter ACS yang tepat untuk setiap kasus yang berbeda-beda.

\section{Daftar Pustaka}

[1] Amalia, R. "Pencarian Jalur Terpendek Menggunakan Ant Colony System (Kasus: Pariwisata Kota Bogor)", Faktor Exacta 8(4): 290-304, Vol 8, No 42015.

[2] Gunawan, A. S. Sipayung, E. M. dan Wiguno, A. "Perancangan Sistem Informasi Penentuan Rute Pengiriman Barang Dengan Metode Ant Colony Optimization Studi Kasus: PT. XYZ", Seminar Nasional Sistem Informasi Indonesia, 2-3 November 2015.

[3] Tutupary, F. S. Talakua, M. W. dan Lesnussa, Y. A. "Aplikasi Algoritma Ant Colony System Dalam Penentuan Rute Optimum Distribusi BBM Pada PT. Burung Laut”, Jurnal Barekeng Vol.8, No.1 2014.

[4] Wardhani, N. "Optimisasi Traveling Saleseman Problem (TSP) Menggunakan Algoritma Semut", Jurnal IT STMIK Handayani, Vol 15, Desember 2014.

[5] Farisi, O. I. R. dan Pratamasunu, G. Q. O. "Penyelesaian Multi-Depot Multiple Traveling Salesmanproblem menggunakan K-Means dan Ant Colony Optimization", Nusantara Journal of Computersand its Applications, Vol 2, No.5 2016.

[6] A.A. Ismail, S. Herdjunanto, Priyatmadi. "Penerapan Algoritma Ant System dalam Menemukan Jalur Optimal pada Traveling Salesman Problem (TSP) dengan Kekangan Kondisi Jalan". JNTETI, Vol. 1, No. 32012.

[7] R. H. Nugroho. "Ant Colony System Algorithm to Solve Multi Depot Vehicle Routing Problem with Travel Time Variable". Tesis Institut Teknologi Sepuluh Nopember 2015

[8] K. Nugroho. "Penggunaan Algoritma Semut Untuk Penentuan Optimisasi Jalur Tim Marketing". Jurnal INFOKAM September 2015.

[9] P. Victor, SN. Azhari. "Ant Colony Optimization on Crowdsourced Delivery Trip Consolidation". IJCCS (Indonesian Journal of Computing and Cybernetics Systems). Vol.11, No.2, July 2017. 